\title{
6
}

\section{DRAWING AND STORYCRAFTING WITH ESTONIAN CHILDREN}

\section{Sharing experiences of mobility}

\author{
Pihla Maria Siim
}

\section{Studying mobile childhoods in the Estonian-Finnish context}

Transnational family studies have stressed the affect that cross-border mobility has on people's family lives, lifestyles, and everyday practices (Bryceson and Vuorela 2002). Individual choices to move are often related to the needs of the family and to family dynamics and are shaped by movement, separation, and reunion. Children are often at the centre of family migration processes: as motivators for migration - to guarantee their wellbeing - or as migrants themselves (Coe et al. 2011, 3-5). In spite of this, the majority of the research on transnational migration has concentrated on adults, the voices of children remaining largely overlooked. Children have rather been treated as non-persons lacking both feelings and agency of their own (Dobson 2009; Punch 2009; Zeitlyn and Mand 2012; Fresnoza-Flot and Nagasaka 2015).

A focus on children within studies of migration and transnational communities is necessary and essential, as children either move across borders or remain where they are under a variety of circumstances, but always affected by the migration of their family members. There are thousands of children involved in migration, encountering changes in their circumstances and environments in the EstonianFinnish transnational space. However, research into children's experiences of intraEU migration is only beginning to emerge (Moskal and Tyrrell 2016, 455). Generally, there is a lack of literature focusing on research into mobile children that helps to understand what it is actually like to be a child affected by migration. Children are not only mobile across places but move through the social roles associated with childhood in particular places (Zeitlyn and Mand 2012, 990; Fresnoza-Flot 2018, 15). "Mobile childhood" thus includes not only spatial, but also temporal and contextual mobility (Fresnoza-Flot and Nagasaka 2015). 
Lately, migration scholars have started to highlight the children's viewpoints and experiences of mobility - not only stressing their vulnerability but also paying attention to their subjectivity, agency and the uniqueness of their viewpoint. This also calls for methodologies more attentive to the everyday, lived experience of migration (Dobson 2009; Coe et al. 2011; Ní Laoire et al. 2011; Fresnoza-Flot 2018). Since 2013 I have studied Estonian families in which some of the family members live or work in Finland. With the first of the research projects (2012-2014) in which I was involved, the focus was solely on children's experiences of migration, and the data was produced with children. ${ }^{1}$ The aim of the project was to focus on the ways children comprehend migration in East and North Europe, and on their descriptions and interpretations of translocal family life (Assmuth et al. 2018).

Since the 1990s, Finland has been the main destination country for migration from Estonia. In the 2000s, emigration from Estonia to the longer-serving EU member states grew, while at the same time the proportion of labour migration increased significantly. Estonians compromise the largest group of foreign citizens in Finland. According to Population Register Estonia, there were 52400 Estonian citizens living in Finland in July 2019, in addition to which 18500 people had registered a Finnish contact address. According to one estimate, in 2012 there were about 30000 people working in Finland but living permanently in Estonia (Statistics Finland 2013). Indeed, Estonia is one of the major countries of origin for commuting workers in Europe: the highest shares of cross-border workers are among Slovakians (5\%), Estonians and Hungarians (just over 2\% each). Men were clearly dominant (92\%) among those who worked abroad but resided in Estonia (European Commission 2019).

Taking into account the number of regular contacts across the border and intensive movement back and forth, it is possible to talk about an Estonian-Finnish transnational space (see Jakobson et al. 2012). In recent years, the volume of emigration has been smaller and return migration has increased. In 2018, Estonia's net migration was positive for the fourth year in a row, and the net migration with Finland was positive for the second year in a row (Statistics Estonia 2019). However, these trends may also change according to the economic and political situation.

Since I started to work with children, I have pondered on whether particular methods should be used. The aim of child-centred methodologies is usually to recognize children as active agents who hold different competencies from adults. However, it should be recognized that childhood is not the same experience for every child, but rather is mediated by the social, cultural and moral norms of each place. Childhood should thus rather be considered a relational experience, one that is influenced by wider social and economic processes, as Zeitlyn and Mand (2012, 990-991) have pointed out.

Keeping this in mind, I started fieldwork with individual and group interviews, interviewing different members of the same family, both children and adults. While interest in narratives has grown in many fields - we can even talk about a narrative 
turn - narrative research has focused mainly on adult narrative and adult life experience (Karlsson 2013, 1110). I did not have previous experience of interviewing children under 14 years old, and it was challenging to figure out how to formulate the right (open) questions for children. I interviewed children either with their parent(s) or alone. Parents were helpful asking additional questions, but they also intervened unnecessarily, disrupting the interview and the connection with a child (see Siim 2016). During the interviews preschool-age children rarely gave long, detailed answers or reflected on their experiences at length. They seemed rather to live in the moment or look towards the future, and not be very eager to talk in detail about what happened in the past.

These experiences lead me to try other kinds of methods in parallel. In this chapter, I will firstly discuss the drawing sessions and related open discussions with children, and then explore in more detail storycrafting and the kind of stories received using this method. Storycrafting is a method that innovatively combines facts with fiction, offering new insights into the experiences of mobile children through a twist that combines the real and the imaginable. Participants are asked to tell imaginative stories, although as our experience shows at the same time these stories reveal a lot about how participants experience and understand the world around them. In this study, children were asked to tell stories, the main characters of which are children of about the same age, moving between Estonia and Finland.

\section{Drawing and discussing with children}

During the 2013-2014 period I regularly visited children's circles and day-care centres in the Greater Helsinki area. In the course of these visits I observed the everyday routines and play of approximately 40 Estonian children during their kindergarten days, making notes. My main interest was in experiences they had that related to mobility and transnational everyday life. Participant observation took a lot of time, leading to information being gained in small pieces, the importance of which was initially difficult to understand. I went through the field notes I had made but felt there was very little in them that was relevant to what I wanted to study.

To recognize the value and character of what one could call "small stories" a "twist" was needed in order to understand and interpret children's experiences. According to Bamberg and Georgakopoulou, more attention should be paid to socalled conversational narratives, and how people actually use these stories in everyday, mundane situations. They have argued for the "worthiness" of stories that they call small stories, both for literal and metaphorical reasons, that are still on the fringes of narrative research. "Small stories" is an umbrella term capturing a gamut of unpresented narrative activities, such as telling on-going events, future or hypothetical events, and shared events. On a metaphorical level it helps to identify the narrative when the fleeting moments of narrative orientation to the world can be easily missed out (Bamberg and Georgakopoulou 2008). 
Keeping in mind that small stories do not have to be long and coherent narratives in order to fulfil their function has helped me to recognize the worthiness of children's short accounts. Their stories might be of a different nature, not resembling the long accounts told by parents during their interviews, but they were still key to the children's world and had intrinsic value. I could now better see the richness and uniqueness of the small details in children's accounts, and started to explore in detail what they noticed and considered worth telling. However, my aim was never to pit the accounts of children and their parents against each other. My attitude was that descriptions that seem to be inaccurate or too fanciful to be "true", in a strict sense, have their own validity and help to understand the child's perspective (Punch 2002, 327).

In qualitative research, it has become more and more usual to use participatory and creative, art-based methods to engage children in order to explore means of communication between children and adults beyond the traditional interview. Creative methods draw on inventive and imaginative processes, and for example storytelling, drama, games, drawing and photography are among the methods often applied (see Veale 2006; Gillies and Robinson 2012; von Benzon 2015). Apart from taking part in daily kindergarten activities, I also decided to organize drawing sessions in small groups with children aged four to seven, asking children $(n=16)$ to make drawings based on certain themes. The first task was to make drawings about visiting Estonia or something they miss from Estonia. The children drew for example buildings located in Estonia (their home or the houses of their relatives, their kindergarten), often also the natural surroundings of these buildings; some drew beaches or the ferry journey across the sea to Estonia.

The task for the second session was to draw something that the children like in Finland, which turned out to be a more difficult assignment. Some children drew their house in Finland, others decided to draw Estonia (for example kindergarten or a beach) instead of Finland. Some drew their dreams, and some asked whether they could draw the globe. Often, when children are drawing, they have a mutual affect and learn from each other (see Thompson 1999). In this drawing session, several of the boys attending ended up drawing similar images, although the related discussions were somewhat different:

Kevin $^{2}$ (7) was the one who delayed drawing longest. He wanted to draw something from his dreams (as did Gerli and Marten), but then noted that he could not draw his dream. He also stated that he could not draw anything from Finland, only from Estonia. Then he asked, whether he could draw the whole globe. "This is Mars. Mars has this kind of hole, doesn't it?" He also asked which was the biggest country, Finland, Estonia or Russia, then answers himself: Estonia. Marten teaches Kevin: Mars has two moons. Kevin says: "the globe is my dream world".

[...] Eventually Rainer (7) asked, whether he could draw the globe. "Does it mean you like it everywhere?" "Yes". It was interesting to observe, what countries Rainer put on the map. "Here is Estonia, here is Russia. From here I 
have travelled by boat. Up there is Lapland". The continents in his drawing were surprisingly correctly sized and shaped in relation to the sea (and in comparison to the drawings made by other children). Rainer also talked about his father's language skills. "Father knows all the languages. German, Russian, English. He is wise like crazy”. (Field diary, Pihla Maria Siim, April 2014)

In the research we used drawings to discover what children consider important in their lives, in order to avoid imposing adult-centred concerns (Punch 2002, 331). When performing task-based methods, such as drawing, the initial interaction is between children and the medium (here paper), and the familiarity with the researcher can be built up over time (ibid., 336). An important part of drawing sessions was also the related discussions. In my study, I would not consider it possible to interpret the drawings outside the narrative context and the explanations given by the children themselves. As Kinnunen (2015) has stated when studying children's spontaneous drawing in a kindergarten context, that drawing is often a kind of dialogue between marks (made on paper) and thoughts. Even more important than the drawings can be to follow and analyse the process of telling and drawing: how children live the drawing, are present in them (Viljamaa 2012, 84-87). This field diary describes a session when Linda draw things she missed about Estonia:

Linda (5 years old) took the assignment quite seriously. She said she missed her grandmother and her dog Timmu. Linda said she now lives on the ground floor, and that in Estonia she had lived on the 3rd floor. She was travelling to Estonia to visit her grandmother the following day. She was carefully drawing her grandmother's house, and she definitely wanted to take her drawing home to surprise her mother. Next to the grandmother's house, she drew a pumpkin, although she said granny does not really grow pumpkins. Her granny lives in the middle of a forest. Next to the house, she also drew an apple tree and asked me to help her to draw Timmu, the dog. So, I agreed and tried to draw a dog according to her instructions. It looked more like a cat. Linda said it didn't matter, since her granny used to have a cat too, but it disappeared into the forest. Linda also included the Estonian flag in the drawing. She said she has four grandmothers. At first she thought she had five, but then she used her fingers to count. I asked whether she also has grandfathers. Yes, she has two. "One of them is really funny", Linda said, "a bit fat, just enough", she added. Grandad calls Linda "Masha" (as in the popular Russian cartoon Masha and the Bear). When Linda's cousin is around, grandpa calls them the two Mashas. (Field diary, Pihla Maria Siim, March 2014)

Adult researchers might be confused about the invitation to draw with the children (see Kinnunen 2015) - how would this affect the material and analysis of it? Children, however, do not usually separate doing, knowing and different types of telling, but move between them rather effortlessly (Viljamaa 2012, 84). These drawing sessions offer the possibility to access embodied and emplaced experiences, 
which may otherwise be hard to verbalize. In the drawings related to visits to Estonia, there were many references to what children did, experienced and sensed (see Bankovska and Siim 2018). In addition, the drawing sessions created a space for diverse and spontaneous narration, as well as the possibility to negotiate the experiences among children. The drawings and stories of other children served as an inspiration and helped them talk about personal experiences.

\section{Storycrafting as a method}

While planning a new project for 2016-2018, I wanted to continue working with children. In addition to drawing, of which I now had some experience, I was interested in trying storycrafting. The storycrafting method was created by Finnish education scientists in the 1980 s to make the interactive relationship between adults and children more equal, and to inspire and encourage children to tell about their own world and thoughts (Riihelä 1991; Karlsson 2013). When applying storycrafting methods, the child is asked to tell a story, the researcher writes it down, word for word, and reads it aloud to the child, after which the child may correct the story until s/he is content with the outcome. I was inspired and sanguine about the new kind of knowledge this method could possibly produce. By giving research subjects the possibility to tell fictional stories, it kind of pushes the limits of ethnographic knowledge, which often is based on observation or transmission of information of (presumably) factual events, either verbally or visually.

My earlier experience had proven that during the drawing sessions it was relatively difficult to manage all the tasks alone: to help children in practical matters, discuss the drawings with them, and make notes about what is taking place and discussed during these gatherings. Children also expected me to be part of the activities in many ways: sharpening pencils, helping them drawing, being around and interested in what they were doing. From the beginning, we - our project team - planned that in the new meetings with children, two researchers would be involved, my colleague, ethnologist Keiu Telve, and I.

We modified the method a bit - i.e. we have worked with small groups, mostly two to four children, and given children a certain broad theme for the story, so that the stories told are to some extent related to mobility, living in Finland, or a transnational way of life. We asked children to make up a story in which the main character, a child of their age, moves to Finland and goes to school there, and to write about the things s/he likes to do. In some groups we asked children to tell stories related to growing up (future of the main character); about friendship; about holidays in Estonia; where the main character's favourite places are in Finland; or about Christmas celebrations.

We organized 27 storycrafting sessions in 2018, all of which took place in the Greater Helsinki area, with in total 66 children from Estonia from nine different schools and kindergartens. In order to organize the gatherings, we contacted Estonian kindergarten teachers as well as the teachers giving Estonian language lessons in different schools in this area. In Finland, children whose native language 
is not Finnish or Swedish may receive lessons on their mother tongue. In many cases, pupils from different classes and of different ages take part in these lessons. If the teachers were willing to co-operate, and gave us permission to work with the children they taught, the parents were asked to give written consent for their child to participate. The children who had permission were invited to participate in the storycrafting sessions in the library or some other free room, while other pupils attended Estonian language lessons at school or other activities in kindergarten. ${ }^{3}$ In the publications, we have agreed to use pseudonyms for all research participants.

The language of the storycrafting sessions was Estonian. If the children did not remember some words in Estonian, they used Finnish instead. The participating kindergarten children were 3 to 6 years old, and the schoolchildren 7 to 14 years old. From the 27 stories written during these sessions, seven were created by preschool children, and 20 by schoolchildren. Some of the stories were created by one child only, but usually several children participated. When the story was finished and we read it aloud to the children, they usually did not suggest any changes, but were rather eager to start drawing a related picture.

During the fieldwork, children received us extremely well both at the kindergartens and schools. The school aged children were particularly active and keen to participate in the storycrafting and drawing sessions. Presumably the sessions resembled their everyday activities and were somewhat similar to children's spontaneous, everyday storytelling situations. We noticed that the children felt more relaxed than they usually do in interview situations when a researcher is asking questions, at which times the children feel stronger pressure to answer relatively quickly and to do so in the "correct" manner. One benefit is also that drawing and storycrafting gives children more time to think: the image and story can be changed and added to, which gives children more control over their form of expression (see Punch 2002). Children were also motivated to participate, since they were aware of our plan to publish a children's book (Siim and Telve 2019). This book, published in November 2019, contains all the 27 stories written down during the storycrafting sessions, complemented with short citations from our field diaries, conversation questions, and drawings made by the children. The book is directed to a wider audience, for example families with children who are considering relocation. The aim is to offer families both inspiration and food for thought, to make them aware of the ways children understand and experience mobility and make it easier to start a discussion with their family members.

\section{New twists: interplay of factual and fictional}

Although the stories created by children are rich in fantasy and created in collaboration with researchers, they essentially draw on children's everyday experiences and observations. The stories combine personal experience and fantasy in a fascinating way, revealing what details children notice, what kinds of discussion and comment they remember, what kinds of situation they consider imaginable and what kinds of emotion they ascribe to children of their age. To start with, we gave 
the children a broad theme for their stories, as explained above, although what followed was for them to decide. Some of the stories were really fanciful, others seemed to draw more on children's personal experiences. I have chosen these two excerpts from the stories because they show the variation that exists:

"Raili's story"4

Raili is 12 years old and lives in Finland with her mother. She also has a little brother. Their house is black. Their parents have divorced and their father lives in Estonia. Because Raili's mother has two children and a low salary, they live in Finland. (Girls, 10 and 11)

"Adventures of Kaspar and Jasper"

Kaspar and Jasper lived in Finland. Jasper's mother liked the nature in Finland. Kaspar's mother thought it would be easier for Kaspar to learn in Finland. They moved back to Estonia, since they missed it a lot and there was some kind of explosion in Finland and so they had to fly to Estonia. [...] They still speak Finnish but use it rather rarely, although there are a lot of Finns living in Estonia because of the explosion that took place in Finland. (Boys, 9 and 10)

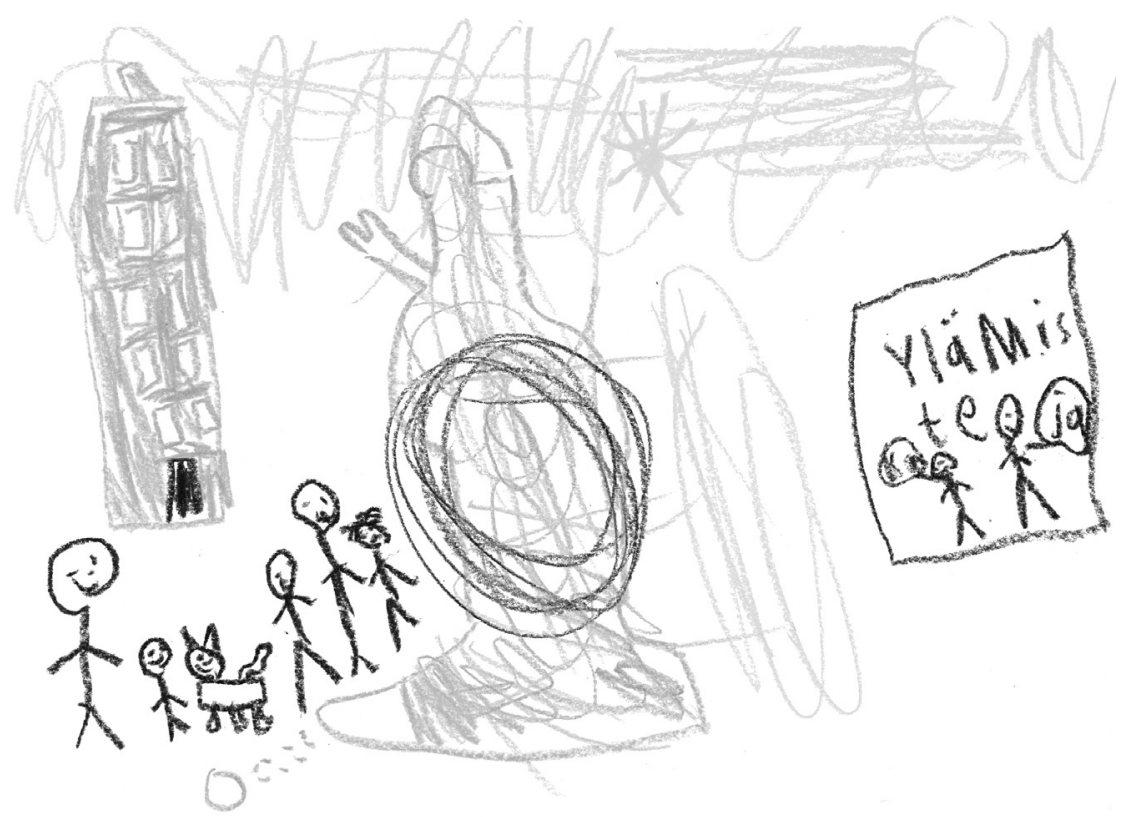

FIGURE 6.1 Drawing by a 9-year-old boy, 2018. Copyright: Inequalities in Motion: Transnational Families in Estonia and Finland project. 
On the one hand, these stories include a lot of detail, presumably observed by children in their everyday lives, or adopted from adults' discussions they have heard. For example, in many of the stories, the main character has moved to Finland because the parents of the family need to work there in order to earn a better income. Stories also include realistic descriptions of family relations, friendship, school life and bullying, and about everyday materialities (such as food, household equipment, and children's toys). On the other hand, as the second story shows, the stories also include elements of fantasy that the children themselves have made up, or about which they dream. They talked, for example, about an explosion in Finland that forces Finns to move to Estonia; about a private aeroplane which the main character can use freely; the possibility of buying things without money; and about a secret children's hut in the middle of the forest.

When starting with the story, the most difficult task for children was often to name the main character in the story. Sometimes there were also disagreements among children about the course of the events in the stories. For example, in one group all three participating girls were very talkative. I felt that two of them knew each other slightly better, and the third one was kind of left out and her suggestions for the storyline were not readily accepted. On the other hand, this might have been also a question of language: her Estonian language skills were not as good as the others.

In the case of two boys aged 9 and 10, I felt that one of the authors would have preferred a more fanciful story, but the other participating boy did not accept all the ideas he suggested. The same was the case with a story called "Jokker", created by two boys from another school in Helsinki. One of the boys suggested that a bus would pick Jokker up from school, and that there would be "moneybombers"; in addition, there are drunk people and smokers around. However, the other author said he did not want to have these details in the book. The story was written down as follows:

A boy called Jokker moves from Estonia to Finland. He moves together with his mother and father; they also have two cats and a dog. They put all their stuff into a big "work bus" and take the boat to Finland. Only knives are not allowed. They take clothes, Lego, hunting knives, and also food: coca cola, sweets, spaghetti. They'll travel back and forth and are able to bring more stuff from Estonia. On the boat, Jokker always takes a VIP cabin. If he doesn't, he hangs around, although he doesn't like that too much. He likes to travel with Mega Star [a ship built in 2017, travelling between Tallinn and Helsinki], and if he can't take this ship he doesn't want to travel at all. All of his friends are aboard Mega Star and there is a room of game consoles that is free of charge, rather than for two euros, which is the usual price. On the boat he eats a hamburger and potato chips and says "Goodbye, Estonia!" It's always fun on the boat. Jokker would like the trip to last longer than two hours. In Finland he lives in Kulomäki [a district in Vantaa, in Greater Helsinki]. The first thing he sees in Finland is a golden house, which is his home. There are Nintendos 
and similar things in his Finnish home. The Estonian home was better, since Estonia is his homeland and he was able to be free there. In Finland he needs to go to school, but Estonian school is worse actually. Mother comes to pick him up from school. While waiting for her, Jokker plays with his phone. He also checks the answers for his homework on the phone. He also plays football. He likes how in Finland you don't need to pay for electricity or for water. When Jokker grows up he will work as a policeman in Finland, he won't move back to Estonia. However, before his death he will return and he will be buried there. (Two 8-year-old boys)

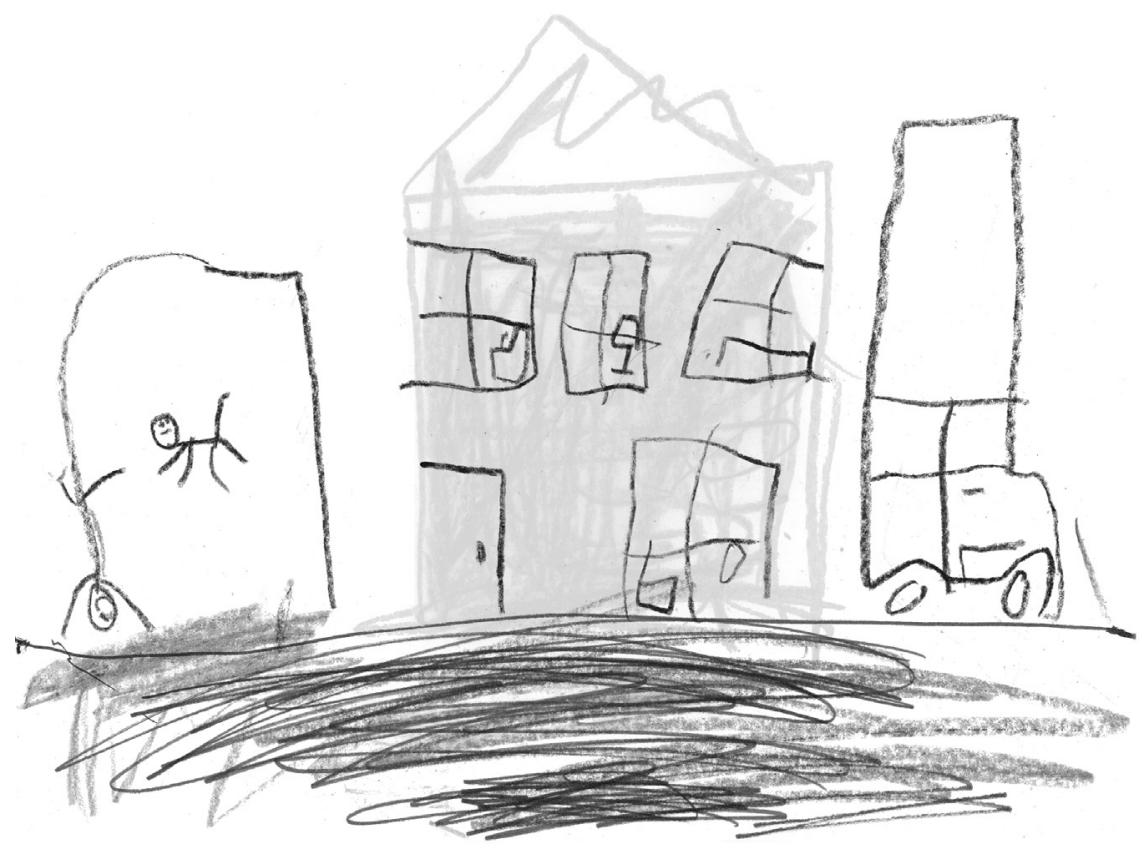

FIGURE 6.2 Drawing by an 8-year-old boy, 2018. Copyright: Inequalities in Motion: Transnational Families in Estonia and Finland project.

I'll draw a golden house. On the second floor, there's a bed in one room, a television in another, a third room is a games room. Outside there's a swimming pool. On the first floor there's a living room. Outside there's the bus they moved with. Jokker is swimming in the pool with his cat.

As Zeitlyn and Mand (2012, 997-998) have pointed out, in group interviews one or two dominant members might emerge who direct the conversation, with others tending to follow their more confident and articulate peers. Working with groups of children does offer the possibility to observe peer relations and the shifts in 
power relations. However, it also ideally inspires "naturalness", i.e. children are usually less shy than when meeting them individually. They can build on each other's statements and discuss a wider range of experiences and opinions than may develop in individual interviews (Eder and Fingerson 2001, 183).

\section{Emotionally loaded stories}

As the previous examples indicate, stories also embody the emotions children may have in relation to translocal everyday life, and to their many homes. Sometimes love of both countries is stressed, as described by two girls aged 9 and 10 in their story:

Children like to live in Finland. No country is bad for living. Everyone likes their own country, but these children like both their homeland and the country they live in now, that is Finland.

Some of the emotions described in stories are related to the children's new homes. For instance, in two stories, the main character has a golden house in Finland. However, in the story cited above, the Jokker's Estonian home was said to be even better, "since Estonia is his homeland and he was able to be free there". However, Jokker will not move back to Estonia, but rather "before his death he will return and he will be buried there". This is a somewhat surprising ending to a story told by two young boys, although some adults I have interviewed have reported similar dreams, i.e. they would like to return to Estonia after retirement and spend the rest of their lives there.

Stories often refer to a child's longing for Estonia. Usually the main character misses his/her parents, grandparents, or other relatives. Time spent in Estonia is described in warm tones. In a story about Annika, the four 6-year-old girls who wrote the story have her go to Estonian during the summer holidays, where she is allowed to do things that are usually forbidden. "She likes to be in Estonia and her grandmother gives her a lot of sweet things, also cacao. She likes how her grandmother doesn't scold her, since she's a very good girl. Annika may even put hair dye on her head. Grandmother has a puppy and a kitten, Tessa and Bella. Annika is very eager to go already". Animals waiting in Estonia are often mentioned in the stories, as well as relative's gardens. "Grandma has a beautiful, old house, surrounded by an apple tree and grass. They call to grandmother to say they arrived and she comes to the door and hugs the child on the stairs" (four 6year-old girls).

This feeling of warmth, both in a figurative and a very concrete fashion, is also present in drawings. In this picture, related to the story quoted above, the author has drawn a dog and a cat, and two suns "since it is very warm in Estonia". The number 100 refers to the warmth, to the high temperature during the summer. In front of the house you can also see the Estonian flag, with its blue, black and white bands. 


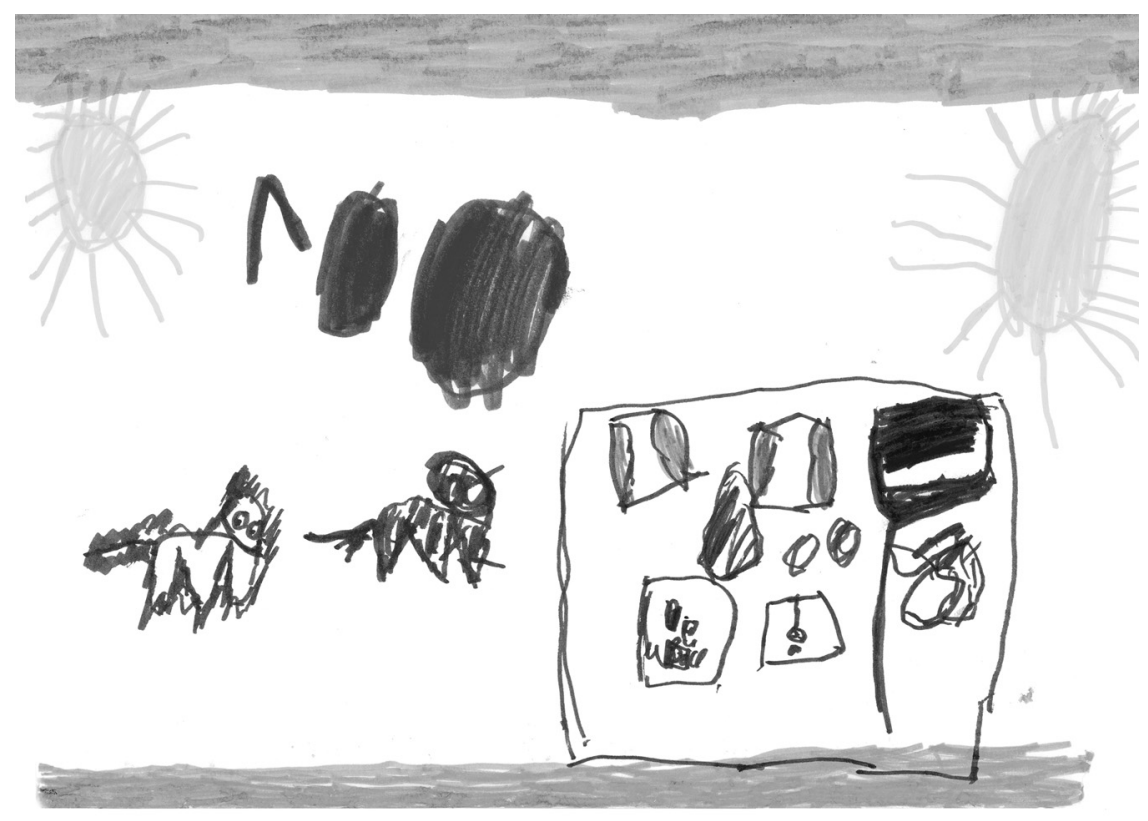

FIGURE 6.3 Drawing by a 6-year-old girl, 2018. Copyright: Inequalities in Motion: Transnational Families in Estonia and Finland project.

Our storytelling sessions have confirmed that fictional storytelling often provides an easier way for the children to talk about their personal experiences, wishes, fears and other emotions. As von Benzon $(2015,338)$ has put it, telling a story may require less conscious evaluation and decision-making than answering a question. During the storytelling sessions with us the children often reflected at length on their own experiences. Working in groups makes it possible for children to share and negotiate these with each other.

In their stories the children also touched on situations that included emotionally distressful experiences, such as the following story which describes in detail the emotions of the main character when her father moved to Finland. I did not meet this kind of story when interviewing the children: usually they said they did not remember how they felt at the time the family moved to Finland. The same applies to friendship and bullying at school: in the interviews these might be mentioned briefly, although they are usually dismissed.

When Eva's father moved to Finland, Eva was 6 years old. Her father moved to Finland because he couldn't earn enough in Estonia and couldn't find a job. Eva didn't understand too much at that age, she knew only that she would see her father during the holidays. Eva's father came home approximately every two months. When her father went back to work, she cried a lot. She would have given everything to see her father every day. It was not easy to move to 
Finland, since she had friends in Estonia. Some of them were angry with her, and didn't care about her anymore, although some continued to be her friend. (Girl, 12)

\section{Conclusion}

Storycrafting helped us obtain a unique picture of children's translocal everyday lives. In the stories created during the sessions, children vividly described their relationships with other children at school, portrayed the futures of the main characters, and playfully sketched children doing things they are not normally allowed to do. Stories also include plenty of children's observations of everyday life, for example regarding financial matters, gender roles and the working conditions of family members.

In storycrafting sessions, participants are given an opportunity to decide what story they would like to share with others. In our case, the most important advantage the method offered was that it allowed participants the possibility to play with the idea of what could happen to a child like them who moved between Estonia and Finland. As compared to interviews, in storycrafting sessions participants tend to talk more about the emotional side of children's lives, for example what they imagine children dream about and what they fear; the emotions children have in relation to homes left behind and about children's special relationships with their grandparents. One of the stories told to us ends with the sentence: "Sometimes in Finland this longing for Estonia comes, but he does not talk about it to others". One aim of the method was to enable children to talk about subjects that they do not usually touch upon. The method allows the possibility to overcome some disadvantages that conventional interviews with children present. It may, for example, be challenging for children to verbalize memories, to find the right words to describe abstract processes; or they may tire quickly during interviews (Zartler 2014), feeling that the themes proposed by adult researcher are not relevant to them. As compared to interview, storycrafting and drawing call for different kinds of co-operation between the participants. The researcher also needs to be ready to take steps in the direction of co-creation. Ideally, storycrafting and drawing sessions help to create a shared space and through this also the conditions for a peaceful encounter that leads to child-oriented storytelling (see Kinnunen 2015).

By intentionally giving room to interplay of the real and the imaginary, storycrafting explores the limits of knowledge achievable through ethnographic methods. However, one should keep in mind that in all ethnographic fieldwork, and in the material it creates, factual and fictional elements are often intertwined, whether the participants are adults or children. In narrative research, the aim of the research is usually not to figure out what exactly happened in people's lives, but rather to concentrate on the interpretations that the research participants have of the incidents, for example how narratives are performed and used in identity projects. For me the most important elements in the stories created during the storycrafting sessions are the emotions, interests, and viewpoints they convey. Children have had 
the possibility to decide what stories will be written down. For them, fiction contributions can be a way to lend their voice to research, contributions that say something valuable about the perspective of the child and of children. In fact, they might tell the researcher more about children's interests than factual accounts (von Benzon 2015, 338).

Researchers have referred to the dynamic and open nature of children's attempts to understand the world, and their interest in crossing and manipulating borders between different ways of narrating. We still know little about the ways in which children move back and forth between the literal and the nonliteral, the real world and the imaginary (Engel 2006, 208-210). The stories created during the storycrafting sessions give the possibility to glimpse children at play, watch them interweave fact and fiction, highlight children's ideas and their ways of thinking. In addition, theses fiction stories and the related discussions may help children to work through their experiences and make sense of the world and their place in it (Nicolopoulou 1997, 208).

Our experiences from the storycrafting sessions indicate that carrying them out might be challenging, but when done the results are rewarding. Data generated using creative methods do not conform to the narrow definitions of reality and truth, but rather open up the ways that people organize and represent their experiences to exploration (Veale 2006). Finally, creative methods such as those described here have been more in use with children - it would be exiting to try this with adults as well.

\section{Notes}

1 Families on the Move: Children's Perspectives on Migration in Europe (2012-2014). I continued to work with children on the Inequalities in Motion: Transnational Families in Estonia and Finland project (2016-2018), both funded by the Kone Foundation, Finland, and lead by Professor Laura Assmuth, University of Eastern Finland. Writing this article was supported by the Estonian Research Council's Performative Negotiations of Belonging in Contemporary Estonia (PUT PSG48) grant (2018-2021, PI Dr Elo-Hanna Seljamaa, University of Tartu).

2 I use pseudonyms when referring to the research subjects. Fieldwork notes and stories created during storycrafting sessions were translated from Finnish and Estonian to English by the author.

3 As experienced by Honkanen et al. $(2018,119)$ not all parents gave permission for their children to participate in the sessions, even when the child was willing. This shows how children lack the power to make decisions on matters that concern themselves.

4 Initially when we started to organize storycrafting sessions in kindergartens, we did not ask children to give titles to the stories, although we later did so with schoolchildren.

\section{References}

Assmuth, L., M. Hakkarainen, A. Lulle, and P. M. Siim, eds. 2018. Translocal Childhoods and Family Mobility in East and North Europe. Cham: Palgrave Macmillan.

Bamberg, M., and A. Georgakopoulou. 2008. "Small stories as a new perspective in narrative and identity analysis". Text \& Talk 28 (3): 377-396. doi:10.1515/TEXT.2008.018 
Bankovska, A., and P. M. Siim. 2018. "And so the journey begins: An embodied approach to children's translocal materialities". In Translocal Childhoods and Family Mobility in East and North Europe, edited by L. Assmuth, M. Hakkarainen, A. Lulle, and P. M. Siim, 39-61. Cham: Palgrave Macmillan.

Bryceson, D. F., and U. Vuorela. 2002. "Transnational families in the twenty-first century". In The Transnational Family. New European Frontiers and Global Networks, edited by D. Bryceson, and U. Vuorela, 3-29. Oxford: Berg Publishers.

Coe, C., R. R. Reynolds, D. A. Boehm, J. M. Hess, and H. Rae-Espinoza, eds. 2011. Everyday Ruptures: Children, Youth, and Migration in Global Perspective. Nashville: Vanderbilt.

Dobson, M. E. 2009. "Unpacking children in migration research". Children's Geographies 7 (3): 355-360. doi:10.1080/14733280903024514

Eder, D., and L. Fingerson. 2001. "Interviewing children and adolescents". In Handbook of Interview Research, edited by J. F. Gubrium, and J. A. Holstein, 181-202. London: Sage.

Engel, S. 2006. "Narrative analysis of children's experience". In Researching Children's Experience. Approaches and Methods, edited by S. Greene, and D. Hogan, 199-216. London: Sage. doi:10.4135/9781849209823.n11

European Commission2019. Annual Report on Intra-EU Labour Mobility. Final Report December 2018. European Commission. Luxembourg: Publications Office of the European Union. https://ec.europa.eu/social/BlobServlet?docId=20685\&langId =hu

Fresnoza-Flot, A. 2018. "Rethinking children's place(s) in transnational families: Mobile childhoods in Filipino international migration". In Childhood and Parenting in Transnational Settings, edited by V. Ducu, M. Nedelcu, and A. Telegdi-Csetri, 11-24. International Perspectives on Migration, vol. 15. Cham: Springer.

Fresnoza-Flot, A., and I. Nagasaka. 2015. "Conceptualising childhoods in transnational families: The 'mobile childhoods' lens". In Mobile Childhoods in Filipino Transnational Families. Migrant Children with Similar Roots in Different Routes, edited by I. Nagasaka, and A. Fresnoza-Flot, 23-41. Basingstoke: Palgrave Macmillan.

Gillies, V., and Y. Robinson. 2012. "Developing creative research methods with challenging pupils". International Journal of Social Research Methodology 15 (2): 161-173. doi:10.1080/ 13645579.2012.649407

Honkanen, K., J. Poikolainen, and L. Karlsson. 2018. "Children and young people as coresearchers - Researching subjective well-being in residential area with visual and verbal methods". Children's Geographies 16 (2): 184-195. doi:10.1080/14733285.2017.1344769

Jakobson, M-L., P. Järvinen-Alenius, P. Pitkänen, R. Ruutsoo, E. Keski-Hirvelä, and L. Kalev. 2012. "The emergence of Estonian-Finnish transnational space". In Migration and Transformation. Multi-Level Analysis of Migrant Transnationalism, edited by P. Pitkänen, A. Içduygu, and D. Sert, 159-205. International Perspectives on Migration, vol. 3. Dordrecht: Springer.

Karlsson, L. 2013. "Storycrafting method - To share, participate, tell and listen in practice and research". The European Journal of Social and Behavioural Sciences 6 (3): 1109-1117. doi: $10.15405 /$ ejsbs. 88

Kinnunen, S. 2015. How Are You? The Narrative In-Between Spaces in Young Children's Daily Lives. PhD diss., University of Oulu. http://jultika.oulu.fi/files/isbn9789526210285.pdf.

Moskal, M., and N. Tyrrell. 2016. "Family migration decision-making, step-migration and separation: children's experiences in European migrant worker families". Children's Geographies 14 (4), 453-467. doi:10.1080/14733285.2015.1116683

Ní Laoire, C., F. Carpena-Mendez, N. Tyrrell, and A. White. 2011. Childhood and Migration in Europe. Portraits of Mobility, Identity and Belonging in Contemporary Ireland. London: Ashgate. 
Nicolopoulou, A. 1997. "Children and narratives: Toward an interpretive and sociocultural approach”. In Narrative Development: Six Approaches, edited by M. Bamberg, 179-215. New Jersey: Lawrence Erlbaum Associates.

Punch, S. 2002. "Research with children: The same or different from research with adults?" Childhood 9 (3): 321-341. doi:10.1177/0907568202009003005

Punch, S. 2009. "Moving for a better life: to stay or to go?" In Key Issues in Childhood and Youth Studies, edited by D. Kassem, L. Murphy, and E. Taylor, 202-215. London: Routledge.

Riihelä, M. 1991. Aikakortit. Tie lasten ajatteluun [Time Cards, the Way to Children's Thinking]. Helsinki: VAPK-kustannus.

Siim, P. M. 2016. "Everyday practices of translocal families: Estonian children and a sense of being-in-place”. Ethnologia Fennica. Finnish Studies in Ethnology 43: 12-27. https://journal. fi/ethnolfenn/article/view/65632

Siim, P. M., and K. Telve, eds. 2019. Minu kaks kodumaad. Laste lood elust kahe riigi vahel $[\mathrm{My}$ Two Homelands: Children's Stories of Life Between Two Countries]. Tallinn: Helios.

Statistics Estonia2019. "More births and smaller emigration increased the population figure". 9 May 2019 - news release no 53. www.stat.ee/news-release-2019-053

Statistics Finland2013. "Suomessa työskentelee jo lähes 60000 vierastyöläistä [Already Almost 60000 Guest Workers Working in Finland]". www.stat.fi/artikkelit/2013/art_ 2013-09-23_013.html

Thompson, C. M. 1999. "Peer influences in preschool-kindergarten art classes". Visual Arts Research 25 (2): 61-68.

Veale, A. 2006. "Creative methodologies in participatory research with children". In Researching Children's Experience. Approaches and Methods, edited by S. Greene, and D. Hogan, 254-272. London: Sage. doi:10.4135/9781849209823.n14

Viljamaa, E. 2012. Lasten tiedon äärellä. Äidin ja lasten kerronnallisia kohtaamisia kotona [With Children's Knowledge. Narrative Encounters of a Mother and Children at Home]. Acta Universitatis Ouluensis E 129. Oulu: University of Oulu. http://jultika.oulu.fi/files/ isbn9789514299940.pdf

von Benzon, N. 2015. "'I fell out of a tree and broke my neck': Acknowledging fantasy in children's research contributions". Children's Geographies 13 (3): 330-342. doi:10.1080/ 14733285.2013 .829662

Zartler, U. 2014. "Photo interviews with children: Relating the visual and the verbal from a participation perspective". International Journal of Child, Youth, and Family Studies 5 (4.1): 629-648. doi:10.18357/ijcyfs.zartleru.5412014

Zeitlyn, B., and K. Mand. 2012. "Researching transnational childhoods". Journal of Ethnic and Migration Studies 38 (6): 987-1006. doi:10.1080/1369183X.2012.677179 